\title{
Origin and evolution of sound production in Serrasalmidae
}

\author{
GEOFFREY MÉLOTTE ${ }^{1}$, XAVIER RAICK ${ }^{1}$, RÉGIS VIGOUROUX ${ }^{2}$ and \\ ERIC PARMENTIER ${ }^{1, *, \bullet}$
}

\author{
${ }^{1}$ Laboratoire de Morphologie Fonctionnelle et Evolutive, UR FOCUS, Institut de Chimie, Bât. B6c, \\ Université de Liège, B-4000 Liège, Belgium \\ ${ }^{2}$ HYDRECO Guyane, Laboratoire Environnement de Petit Saut, B.P. 823 - 97388 Kourou Cedex, French Guiana
}

Received 17 May 2019; revised 15 June 2019; accepted for publication 18 June 2019

\begin{abstract}
Among piranhas, sound production is known in carnivorous species, whereas herbivorous species were thought to be mute. Given that these carnivorous sonic species have a complex sonic apparatus, we hypothesize that intermediate forms could be found in other serrasalmid species. The results highlight the evolutionary transition from a simple sound-producing mechanism without specialized sonic structures to a sonic mechanism involving large, fastcontracting sonic muscles. Hypaxial muscles in basal herbivores primarily serve locomotion, but some fibres cause sound production during swimming accelerations, meaning that these muscles have gained a dual function. Sound production therefore seems to have been acquired through exaptation, i.e. the development of a new function (sound production) in existing structures initially shaped for a different purpose (locomotion). In more derived species (Catoprion and Pygopristis), some fibres are distinguishable from typical hypaxial muscles and insert directly on the swimbladder. At this stage, the primary function (locomotion) is lost in favour of the secondary function (sound production). In the last stage, the muscles and insertion sites are larger and the innervation involves more spinal nerves, improving calling abilities. In serrasalmids, the evolution of acoustic communication is characterized initially by exaptation followed by adaptive evolution.
\end{abstract}

ADDITIONAL KEYWORDS: acoustics - piranhas - sonic muscle.

\section{INTRODUCTION}

Numerous teleost fishes are known to produce sounds during reproductive and agonistic interactions (Ladich, 1997, 2015; Myrberg \& Lugli, 2006). However, fish sonic mechanisms appear to have evolved independently in different taxa (Fine \& Parmentier, 2015), which makes it difficult to realize comparative studies based on many taxa, because the origin of the sonic apparatus may be completely different. Within some families, such as Pomacentridae (Colleye et al., 2011), Doradidae (Boyle et al., 2015), Balistidae (Raick et al., 2018), Batrachoididae (Rice \& Bass, 2009) and Sciaenidae (Ramcharitar et al., 2006), species use the same type of sound-producing mechanism. Given that the sound-producing mechanism appears to be highly conserved, it is difficult to understand how acoustic abilities evolved. In other taxa, closely related species

*Corresponding author. E-mail: parmentier@uliege.be can produce different types of sounds with different sound-producing apparatus (Hallacher, 1974; Rice \& Bass, 2009; Parmentier et al., 2011), which suggests evolutionary trends within those taxa.

These groups are interesting because they could be used to define the evolutionary stages leading to the ability to produce sounds. In some taxa, the evolution of sonic mechanisms could be the result of exaptation, by the modification of existing structures that were initially devoted to other functions (Parmentier et al., 2017). For example, fish can make sounds by grinding their teeth or flapping their fins, which evolved for other purposes. Evolutionary trends are more difficult to explain when fishes make sounds with muscles acting on the swimbladder (Ladich \& Fine, 2006; Mok et al., 2011; Fine \& Parmentier, 2015) because their ancestral conditions have to be identified.

According to the most recent studies on piranha phylogeny, Serrasalmidae can be divided into three clades (Orti et al., 2008; Thompson et al., 2014): (1) 
the 'pacu' clade composed of fruit- and seed-eating species (Correa et al., 2007; Anderson, 2009); (2) the 'Myleus' clade, which feed on plants, fruits and seeds (Planquette et al., 1996); and (3) the 'true piranhas' clade, which are more diverse and include herbivorous, omnivorous and carnivorous species.

Over the past few decades, sound production has been described to various extents in only some carnivorous piranha species, namely those in Serrasalmus and Pygocentrus (Markl, 1971; Kastberger, 1981a, b; Mélotte et al., 2016; Rountree \& Juanes, 2018). In these species, extrinsic sonic muscles originate on the base of the second ribs and insert on a broad tendon surrounding the ventral surface of the swimbladder (Ladich \& Bass, 2005; Millot et al., 2011; Mélotte et al., 2016). In herbivorous species, males of Piaractus brachypomus (Cuvier, 1818) emit a 'knocking' sound when females are ready to spawn, but these have not been described fully, and the sonic apparatus is unknown (Dabrowski et al., 2003). No sounds or sonic mechanisms have been described in other serrasalmids.

Within the piranha clade, given that the carnivorous sonic species Pygocentrus and Serrasalmus are the most derived genera and have a complex sonic apparatus (Markl, 1971; Millot et al., 2011), we hypothesize that transitional morphologies could be found in other serrasalmid species. Consequently, we have chosen to investigate sound production in herbivorous species (Piaractus brachypomus, Myloplus rubripinnis, Myloplus schomburgkii, Myloplus rhomboidalis, Metynnis lippincottianus and Acnodon oligacanthus) and in species that are closely related to Pygocentrus and Serrasalmus (Pristobrycon striolatus, Pygopristis denticulata and Catoprion mento) (Orti et al., 2008; Thompson et al., 2014). The aim is to form a hypothesis for the way in which the sonic mechanism has evolved in Serrasalmidae.

\section{MATERIAL AND METHODS}

All procedures and all methods were approved by the ethical commission of the University of Liège (ethics case 1532).

\section{FISH COLLECTION}

Fourteen Piaractus brachypomus [36-147 mm (SL) standard length], ten Metynnis lippincottianus (76$87 \mathrm{~mm}$ SL), three Myloplus rubripinnis (98-108 $\mathrm{mm}$ SL), eight Myloplus schomburgkii (55-82 mm SL), six Pygopristis denticulata (55-138 mm SL) and five C. mento (49-100 $\mathrm{mm}$ SL) were purchased via the aquarium trade. These were housed in freshwater aquaria at $26 \pm 1{ }^{\circ} \mathrm{C}$ and were maintained on a 12 h-12 h light-dark cycle. The tanks were equipped with an external filter, an internal heater, and bubblers for aeration. Piaractus brachypomus, Metynnis lippincottianus, Myloplus rubripinnis and Myloplus schomburgkii were fed with food granules three times a week, whereas Pygopristis denticulata and $C$. mento were fed with mussels three times a week. Additionally, ten A. oligacanthus (105-162 mm SL), eight Myloplus rhomboidalis (76-150 mm SL) and ten Pristobrycon striolatus (90-130 $\mathrm{mm} \mathrm{SL)} \mathrm{were}$ caught with gill nets in March 2015 during a field excursion on the Tampok and Waki rivers in French Guiana (Guiana Amazonian Park).

\section{SOUND COLLECTION AND ANALYSIS}

Sounds were recorded in a tank of $\sim 135 \mathrm{~L}$ (85 cm length $\times 40 \mathrm{~cm}$ width $\times 40 \mathrm{~cm}$ height) using a hydrophone (HTI-96-MIN Series; High Tech Inc., Long Beach, MS, USA; sensitivity: $-164.4 \mathrm{~dB}$ re $1 \mathrm{~V} / \mu \mathrm{Pa}$; flat frequency response range between $2 \mathrm{~Hz}$ and $30 \mathrm{kHz}$ ) connected to a portable stereo recorder (Tascam DR-05). During the recordings, the temperature was $26 \pm 1{ }^{\circ} \mathrm{C}$, and the lighting, external filters and bubblers were turned off to reduce background noise. At each recording session, the hydrophone was placed at the centre of the recording tank. The tank contained a different number of specimens for recording sessions of Piaractus brachypomus, Metynnis lippincottianus, Myloplus rubripinnis and Myloplus schomburgkii. The tank contained two specimens of the same species for recording sessions of Pygopristis denticulata and C. mento. Moreover, the individuals of the different species were recorded when hand-held underwater (20 cm depth), at a distance of $\sim 5 \mathrm{~cm}$ from the hydrophone. In addition to these recording sessions in laboratory conditions, A. oligacanthus, Myloplus rhomboidalis and Pristobrycon striolatus were audiorecorded in a tank directly placed in the field during the fishing expedition. The recording material and the recording conditions were otherwise the same as described previously for the other species.

Sounds were digitized at $44.1 \mathrm{kHz}$ (16-bit resolution) and analysed using Avisoft SAS-Lab Pro v.5.2 software. All recordings were bandpass filtered (band width, 50-2000 Hz for drumming sounds; band width, 50-3000 $\mathrm{Hz}$ for stridulatory sounds) to avoid frequency distortion owing to the resonance of the tank. Temporal features were measured from oscillograms, and frequency parameters were obtained from power spectra. Spectrograms of the sounds were obtained to visualize the frequency components (Fast Fourier Transfrom length, 256 points; frame size, $100 \%$; window, flat top; time overlap, 98.43\%). Given that different types of sounds were recorded, the sound parameters that were measured varied according to the type of sound. For pulsed sounds (type 1), we 
measured the following parameters: sound duration (in milliseconds); number of pulses in a sound; pulse duration (measured as the time from the beginning of one pulse to its end; in milliseconds); pulse period (measured as the average interval between consecutive pulses in the sound; in milliseconds); and dominant frequency (in hertz), which represents the frequency with the most energy in the power spectrum of one pulsation. For warning calls (type 2) (Millot et al., 2011), we measured the following parameters: sound duration (in milliseconds); number of cycles in a sound; first cycle period (measured as the peakto-peak interval between the first two cycles in the sound; in milliseconds); cycle period (measured as the average peak-to-peak interval between consecutive cycles in the entire sound except the first two cycles; in milliseconds); and fundamental frequency (in hertz), which represents the first harmonic in the power spectrum. Pygopristis denticulata produced two types of sound. Five Pygopristis denticulata produced 139, 25,12 , ten and seven sounds of type 1. Two Pygopristis denticulata produced 13 and 14 sounds of type 2 . Five C. mento produced a single type of sound; specimens made $29,14,12,12$ and two sounds, respectively. The individual means were calculated first and the species mean was calculated afterwards.

\section{MORPHOLOGICAL STUDY}

To observe and describe the morphological structures that might be involved in sound production, two specimens per species were dissected. The individuals were euthanized with tricaine methanesulfonate (MS-222) and fixed in 7\% formalin for $\sim 2$ weeks before being transferred to $70 \%$ ethanol for storage. Specimens were dissected at the level of the anterior sac of the swimbladder and examined with a Wild M10 (Leica) binocular microscope equipped with a camera lucida.

According to the sound-production ability of the species investigated, different muscle samples were fixed for $48 \mathrm{~h}$ in $2.5 \%$ glutaraldehyde for observation with an optical microscope (Leica MD 1000). After glutaraldehyde fixation, muscle samples were dehydrated in an ethanol-propylene oxide series and embedded in epoxy resin. Muscular fibre morphology was observed in semi-thin sections stained with Toluidine Blue. The diameter of intercostal/extrinsic and epaxial fibres was calculated using ImageJ software. Muscles included the first epaxial muscles in Pygopristis denticulata (55 mm SL), C. mento (58 mm SL), Piaractus brachypomus (36 mm SL), Myloplus schomburgkii ( $82 \mathrm{~mm} \mathrm{SL)} \mathrm{and} \mathrm{Serrasalmus} \mathrm{spilopleura}$ (98 $\mathrm{mm}$ SL). Additional samples were taken from the same individuals: intercostal muscle (between ribs 1 and 2) in Piaractus brachypomus (36 $\mathrm{mm} \mathrm{SL}$ ) and
Myloplus schomburgkii (82 mm SL); and extrinsic muscle (associated with the anterior chamber of the swimbladder) in Pygopristis denticulata ( $55 \mathrm{~mm} \mathrm{SL}$ ), C. mento (58 mm SL) and S. spilopleura (98 mm SL).

\section{EleCtrostimulation}

In order to localize the body part(s) involved in sound production in Piaractus brachypomus, three specimens $(124,141$ and $147 \mathrm{~mm}$ SL) were used for an electrostimulation experiment. Each fish was placed in an experimental tank (98 cm length $\times 33 \mathrm{~cm}$ width $\times 28 \mathrm{~cm}$ height). Fish were put in a custom-made harness to prevent body movements while allowing normal breathing. The harness was closed dorsally and caudally with clamps attached to a steel frame and placed into the tank. Two subdermal stainless-steel needle electrodes (Rochester Electro-Medical, Lutz, FL, USA) were used to induce electrical stimulation. Different body muscles (anterior hypaxial musculature and posterior epaxial musculature) that surround the swimbladder were then stimulated with both electrodes placed in the same muscle $\sim 5 \mathrm{~mm}$ below the skin. Simultaneously, the hydrophone was placed in the centre of the experimental tank to record the sounds produced during electrical stimulations. The electrostimulator (HSE Stimulator Type 215/T; Hugo Sachs Elektronik, March-Hugstetten, Germany) was set to induce a direct current stimulation of $1 \mathrm{~V}$ lasting $15 \mathrm{~ms}$ every $3 \mathrm{~s}$. Sounds elicited by electrical stimulation were digitized at $44.1 \mathrm{kHz}$ (16 bit-resolution) and analysed using Avisoft SAS-Lab Pro v.5.2 software. Sound duration (in milliseconds) was measured from oscillograms and dominant frequency (in hertz) was obtained from power spectra (Fast Fourier Transfrom length, 256 points; frame size, $100 \%$; window, flat top; and time overlap, 98.43\%). All recordings were bandpass filtered (band width, 50-2000 Hz) to eliminate the resonant frequency of the experimental tank.

\section{STATISTICAL ANALYSIS}

Descriptive statistics were calculated for each temporal and frequency variable of the sounds produced by the different species.

Natural sounds of Piaractus brachypomus were compared with sounds obtained by electrical stimulation of the body areas. The Shapiro-Wilk normality test was used to test the normality of the data. Wilcoxon signed rank tests were used to compare sound characteristics amongst the different sound types.

Linear regressions were performed to examine the relationship between fish size (SL) and acoustic features in Pygopristis denticulata and C. mento. 
Depending on the Shapiro-Wilk normality test results, intercostal/extrinsic and epaxial fibre diameters were compared with Student's paired $t$-test or a Wilcoxon signed rank test in the species investigated. We did not compare fibre diameters between the different species because it was shown previously in Pygocentrus nattereri that muscular fibre diameters vary according to fish size (Millot \& Parmentier, 2014).

Statistical analyses were performed with Statistica v.12 and GraphPad Prism v.5.0. Results are presented as means \pm SD. Significance level was determined at $P<0.05$.

\section{RESULTS}

No sounds were recorded for the species Metynnis lippincottianus, Pristobrycon striolatus, Myloplus rhomboidalis, Myloplus rubripinnis and A. oligacanthus, whatever the recording conditions (i.e. when hand-held or when swimming freely in the recording tank). However, we cannot conclude definitively that these fish are incapable of sound production.

\section{PROPERTIES OF PRODUCED SOUNDS}

When freely swimming, the herbivorous Piaractus brachypomus produced sounds consisting of a single pulse (Fig. 1A). The sound waveform was composed of several cycles, with the initial cycles having the greatest amplitude (Fig. 1A). The sound duration averaged $175 \pm 65 \mathrm{~ms}(N=48)$, with a dominant frequency of $77 \pm 43 \mathrm{~Hz}(N=48)$. In the tank, sound emission was accompanied by the sudden and fast swimming movement of the calling fish. The role of sounds could not be determined. No sounds were recorded when Piaractus brachypomus was held in the hand.

Myloplus schomburgkii also produced sounds consisting of a single pulse (Supporting Information, Fig. S1) during swimming acceleration. It is hard to determine whether these sounds were merely by-products of movements or used for social

b.

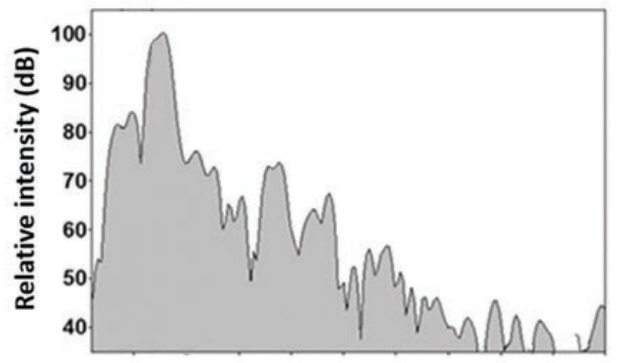

d.

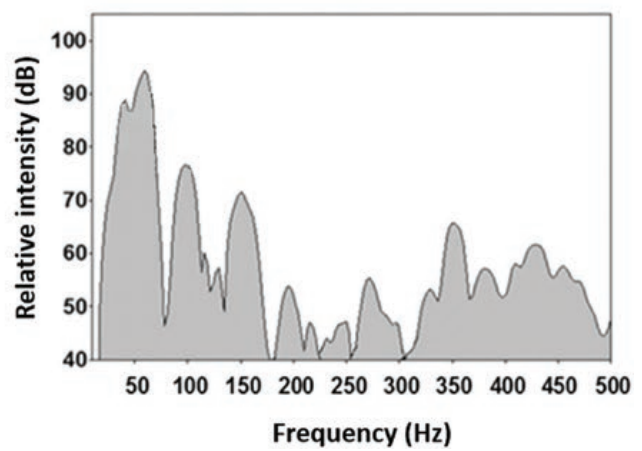

Figure 1. Waveform, spectrogram and power spectrum of the sounds produced by Piaractus brachypomus in natural and electrostimulation situations. A, waveform and spectrogram of a natural sound. B, power spectrum of a natural sound. C, waveform and spectrogram of a sound produced by the stimulation of the anterior hypaxial musculature. D, power spectrum of a sound produced by the stimulation of the anterior hypaxial musculature. The first cycle (indicated by a black arrow) in panel C corresponds to the electrical stimulation. B, D, graphs illustrate the congruence between the main frequency peaks composing the spectra of the natural and electrostimulated sounds. No sound was produced when the posterior epaxial musculature was electrostimulated. Sounds were recorded at $44.1 \mathrm{kHz}$. 
communication. As was the case in Piaractus brachypomus, this sound was composed of several cycles, with the initial cycles having the greatest amplitude. Sound duration was $26 \pm 44 \mathrm{~ms}$, and dominant frequency averaged $77 \pm 20 \mathrm{~Hz}$. No sound was recorded when Myloplus schomburgkii was held in the hand.

Pygopristis denticulata made pulsed sounds emitted in trains. Pygopristis denticulata produced two types of sounds (Fig. 2B; Supporting Information, Fig. S2). The first type (Fig. 2B) consisted of trains of a varying number of pulses (from one to 13) produced at a period of $225 \mathrm{~ms}$ (Table 1). Sound duration averaged $800 \mathrm{~ms}$, whereas pulse duration and period were $\sim 19$ and $\sim 226 \mathrm{~ms}$ (Table 1), respectively. The dominant frequency had a mean of $90 \mathrm{~Hz}$ (Table 1). Sound duration and pulse period were characterized by high SDs (e.g. pulse period varying from 29 to $598 \mathrm{~ms}$ ). a.

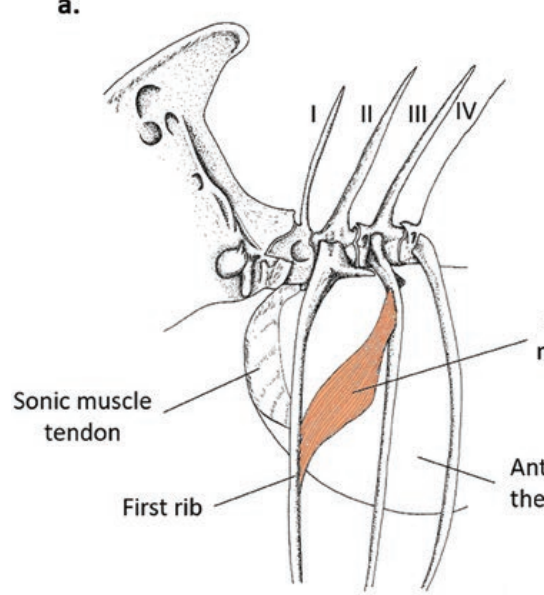

b.

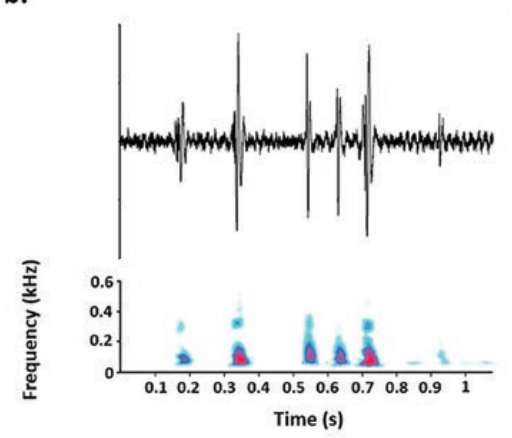

c.

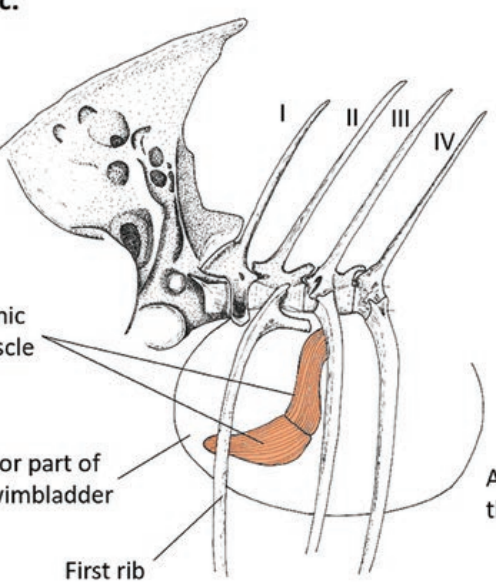

d.

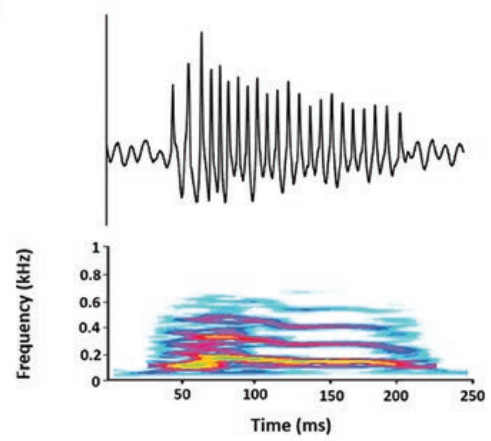

f.

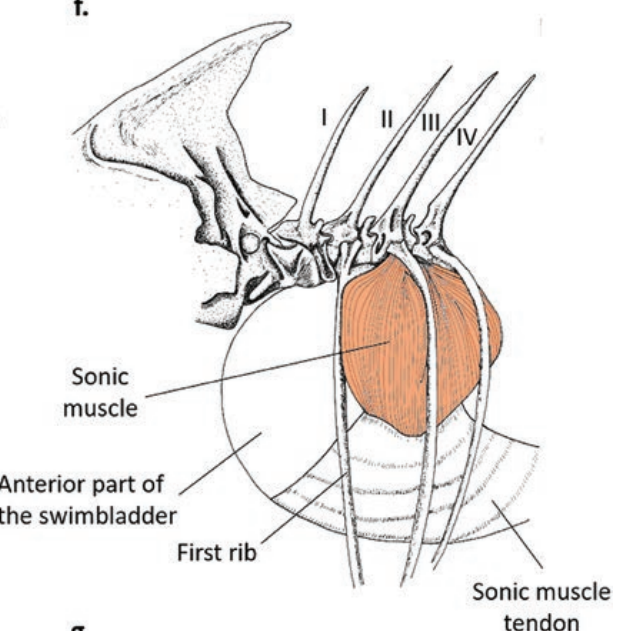

g.

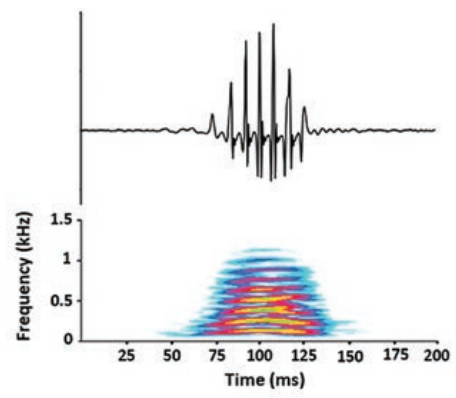

e.

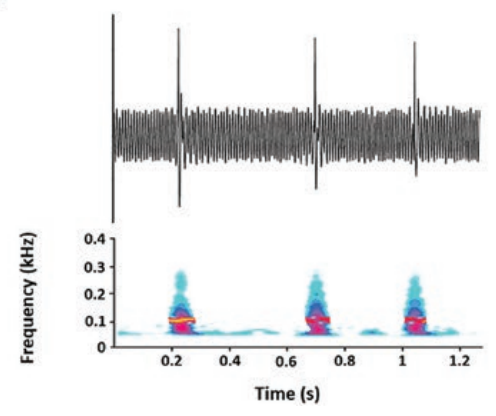

Figure 2. Left lateral view of the sound-producing apparatus and sound waveforms and spectrograms in Pygopristis denticulata, Catoprion mento and Serrasalmus rhombeus. A, B, sound-producing apparatus (A) and pulsed sound (B) of Pygopristis denticulata. C-E, sound-producing apparatus (C), tonal sound (D) and pulsed sound (E) of C. mento. F, G, soundproducing apparatus (F) and tonal sound (G) of $S$. rhombeus. Roman numbers on the drawings refer to vertebra positions. Note that some ossicles of the Weberian apparatus (tripus, intercalarium and claustrum) were removed for greater clarity. Note also that data concerning S. rhombeus were extracted from Mélotte et al. (2016). 
Table 1. Mean values and standard deviations for the six acoustic variables of the pulsed sounds produced by Pygopristis denticulata $(128 \pm 11 \mathrm{~mm} \mathrm{SL})$ and Catoprion mento $(67 \pm 20 \mathrm{~mm}$ SL $)$

\begin{tabular}{lllllll}
\hline Species $(N)$ & $\begin{array}{l}\text { Number of } \\
\text { sounds } \\
\text { analysed }\end{array}$ & $\begin{array}{l}\text { Sound } \\
\text { duration } \\
(\mathrm{ms})\end{array}$ & $\begin{array}{l}\text { Number of } \\
\text { pulses per } \\
\text { sound }\end{array}$ & $\begin{array}{l}\text { Pulse } \\
\text { duration } \\
(\mathrm{ms})\end{array}$ & $\begin{array}{l}\text { Pulse } \\
\text { period } \\
(\mathrm{ms})\end{array}$ & $\begin{array}{l}\text { Peak } \\
\text { frequency } \\
(\mathrm{Hz})\end{array}$ \\
\hline $\begin{array}{c}\text { Pygopristis denticulata } \\
\text { (5); sound type 1 }\end{array}$ & 193 & $800 \pm 520$ & $4.5 \pm 2.4$ & $19.1 \pm 6.4$ & $225 \pm 116$ & $91 \pm 38$ \\
$\begin{array}{c}\text { Pygopristis denticulata } \\
\text { (2); sound type 2 }\end{array}$ & 27 & $688 \pm 504$ & $10.0 \pm 6.0$ & $14.8 \pm 5.6$ & $75 \pm 25$ & $2440 \pm 170$ \\
\begin{tabular}{l} 
Catoprion mento (5) \\
\hline
\end{tabular} & 69 & $348 \pm 324$ & $1.9 \pm 0.8$ & $12.6 \pm 4.8$ & $368 \pm 154$ & $109 \pm 47$ \\
\hline
\end{tabular}

Abbreviations: $N$, number of individuals recorded; SL, standard length.

This first sound type was emitted in an agonistic context, when the sound-producing fish was chasing another fish. The second type of sound was produced in trains of pulses (from 3 to 22 pulses; Supporting Information, Fig. S2) that were produced over a period of $75 \mathrm{~ms}$ (Table 1). This sound type was characterized by the presence of two peaks in the spectrogram $(\sim 185$ and $\sim 2440 \mathrm{~Hz})$. Sound production was always accompanied by a trembling movement. In both types of sounds, sound duration showed a highly positive correlation with the number of pulses (sound type 1, $R^{2}=0.65 ; P<0.001$; sound type $\left.2, R^{2}=0.98 ; P<0.001\right)$. No sound was recorded when Pygopristis denticulata was held in the hand.

Catoprion mento was also able to produce two types of acoustic sounds (Fig. 2D, E). The first type of sound (Fig. 2E) was characterized by a low number of pulses (Table 1), emitted during chasing. Sound duration showed a significant positive correlation with the number of pulses $\left(R^{2}=0.73 ; P<0.001\right)$. The dominant frequency averaged $110 \mathrm{~Hz}$ (Table 1). Catoprion mento produced a second type of sound when hand-held and during frontal display between conspecifics (Fig. 2D). This consisted of a number of repeated cycles $(18.7 \pm 8.3, N=18)$ having a period of $7 \pm 1 \mathrm{~ms}(N=18)$. Sound duration was $150 \mathrm{~ms}(148 \pm 67, N=18)$, and the number of cycles was $19 \pm 8(N=18)$. Sound duration showed a strong positive correlation with the number of cycles $\left(R^{2}=0.92 ; P<0.001\right)$. The first cycle period was not statistically different from the mean cycle period (Wilcoxon signed-rank test; $Z=1.94$, $P=0.056)$. The fundamental frequency had a mean of $130 \pm 18 \mathrm{~Hz}(N=18)$, and the frequency spectrum was characterized by the presence of harmonics (Fig. 2D).

\section{VARIATION IN MORPHOLOGY OF THE SOUND- PRODUCING APPARATUS}

As is the case in all serrasalmid species, the swimbladder of the nine species was divided into an anterior and a posterior chamber (Markl, 1971). In the five species that did not produce sound, and in Piaractus brachypomus and Myloplus schomburgkii, dissections at the level of the anterior part of the swimbladder revealed no particular morphological structures that could be associated with sound production. They all possess the muscles that are classically found in the hypaxial musculature of teleost fishes (Winterbottom, 1974).

In contrast, Pygopristis denticulata and C. mento produce sounds and possess extrinsic sonic muscles associated with the anterior chamber of the swimbladder (Fig. 2A, C). The sonic muscle of Pygopristis denticulata might be homologous to an intercostal muscle. It originates on the anterior proximal surface of the second rib and inserts on the first rib, approximately at the level of the ventral margin of the swimbladder. A tendon originates from the first rib and extends anterodorsally to insert on the ventral face of the first vertebra (Fig. 2A). In C. mento, the sonic muscle is digastric (meaning that it is made of two bellies). The dorsal part of the sonic muscle originates on the anterior proximal surface of the second rib and joins the ventral part of the muscle at about the middle of the lateral surface of the anterior swimbladder. The lower part of the muscle passes under the first rib and inserts on the anteroventral surface of the swimbladder (Fig. 2C). In both species, muscles are innervated by the fifth spinal nerve, which is the spinal nerve of the intercostal space between ribs 1 and 2 .

Epaxial muscles are usually used as the control in muscle fibre comparison (Parmentier \& Diogo, 2006). The comparison between epaxial and extrinsic muscle fibre diameters in Pygopristis denticulata, C. mento and S. spilopleura showed that extrinsic muscle fibres are more slender than epaxial fibres in these three species that make complex sounds (Table 2 ). In the other sonic species, Piaractus brachypomus and Myloplus schomburgkii, no difference was noted between the diameters of epaxial and intercostal fibres. 


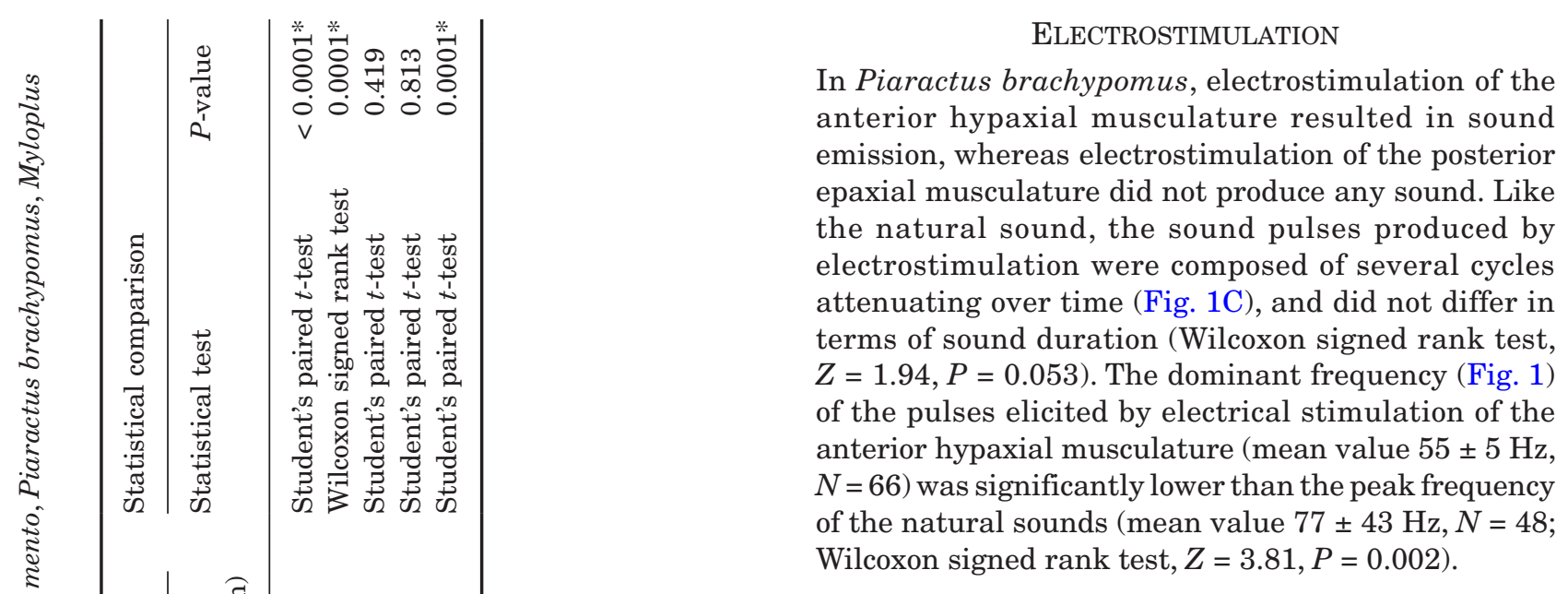

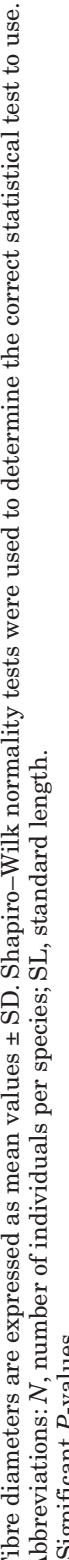

\section{DISCUSSION}

The comparison between morphology and sound production in the framework of known phylogenetic data allows an interesting hypothesis to be constructed describing the origin and evolution of sound-producing abilities among serrasalmid fishes.

Species belonging to the genera Pygopristis, Catoprion, Pygocentrus and Serrasalmus all have extrinsic sonic muscles that have common characteristics. Firstly, all these muscles originate on the second rib. Secondly, their fibre diameter is significantly thinner than corresponding epaxial fibres. It has been pointed out that sonic muscles in Pygocentrus nattereri could simply be neotenic skeletal muscles (Millot \& Parmentier, 2014). The delay in development would explain their smaller size, their restricted quantity of myofibrils, and their increased space devoted to the sarcoplasmic reticulum, characteristics that are usually found in muscular fibres that have invested in high-speed contractions instead of force development (Rome et al., 1996; Millot \& Parmentier, 2014). Thirdly, they are innervated by spinal nerves, which therefore support the argument that they are derived from body musculature. Moreover, these nerves are all found in a segment-like region across the most caudal hindbrain and rostral spinal cord, a region that is known to house vocal circuits (Bass et al., 2008). Therefore, the modified muscles derived from hypaxial musculature are postulated to be the sonic muscles.

Observations made on the herbivorous species Piaractus brachypomus and Myloplus schomburgkii support the hypothesis that the sound-producing mechanism in serrasalmids finds its origin in the modification of the hypaxial musculature. These fish lack the sonic muscles closely associated with the anterior sac of the swimbladder. Electrostimulation experiments on 
hypaxial muscles in pacu Piaractus brachypomus, in addition to the observation that sounds were emitted simultaneously with a fast swimming movement in both herbivorous species (Piaractus brachypomus and Myloplus schomburgkii), suggest that pulse emission results from the contraction of the anterior hypaxial musculature. Histological cross-sections failed to show smaller fibres in these hypaxial muscles. This unmodified muscle might produce sounds that are restricted to single pulses because they are not able to sustain fast contractions in order to develop a train of pulsed sounds. The hypothesis that these anterior hypaxial bundles are the precursor to the drumming muscles found in carnivorous species is also reinforced by soundproduction abilities in at least some prochilodontids (e.g. Semaprochilodus insignis, Prochilodus argenteus, Prochilodus costatus, Prochilodus lineatus) (Godinho et al., 2017; Smith et al., 2018; Borie et al., 2019) and anostomids (e.g. Megaleporinus muyscorum, Leporinus microcephalus) (Reynalte-Tataje et al., 2013; Ramirez et al., 2017). Both of these families are in the same monophyletic clade (Anostomoidea), which is thought to be the sister group of Serrasalmidae (Calcagnotto et al., 2005). In Anostomoidea, known sound-producing taxa, sounds appear to be made by intercostal muscles associated with the first four ribs (Schaller, 1971; Ramirez et al., 2017). The muscles are dark red in colour in reproductive males, suggestive of a high concentration of myoglobin. This shows that these muscles are fatigue resistant (Ordway \& Garry, 2004) and able to produce long trains of pulses (Godinho et al., 2017; Smith et al., 2018). Note that sonic muscles in Prochilodontidae, Anostomidae and Serrasalmidae are all from the same body part: hypaxial muscles related to the first ribs.

Animal communication theory holds that many signals evolved from non-signalling behaviours through the process of ritualization: activities not associated with communication, such as locomotory movements or breathing, are co-opted to create new communication signals (Tinbergen, 1952; Randall, 2001; Scott et al., 2010). The evolutionary transition from a simple sound-producing mechanism without specialized sonic structures in Piaractus brachypomus and Myloplus schomburgkii to a sonic mechanism involving, e.g. large fast-contracting sonic muscles, in the genera Pygocentrus and Serrasalmus allows a hypothesis to be proposed concerning the evolution of sound production within the serrasalmids. Hypaxial muscles in Piaractus brachypomus and Myloplus schomburgkii primarily serve locomotion, but some bundles were co-opted to sound production, thus gaining a dual function. Sound-production capabilities therefore seem to have been acquired through exaptation (Parmentier et al., 2017), i.e. the development of a new function (sound production) in existing structures initially shaped for a particular purpose (locomotion). Sounds in Piaractus brachypomus were observed to be a by-product of swimming movements in the present study but were also reported to be produced by the male during spawning activities (Dabrowski et al., 2003).

In the piranha Pygopristis denticulata, the sonic muscle does not attach to the swimbladder, it joins the first rib to the second rib (Fig. 2A). We postulate that these sonic muscles are derived from fibres of the intercostal obliquus inferioris muscle, because they pass from anteroventral to posterodorsal (Winterbottom, 1974). This observation reinforces a previous hypothesis about the localization of the sound-producing muscle in some herbivorous species. It is suggested that by using these muscles, Pygopristis denticulata is able to produce isolated pulses only. Interestingly, trembling movements of Pygopristis denticulata could also testify to the dual function of the muscle during fish communication. In other piranha species, sound-producing muscles attach to the swimbladder either directly (C. mento) or indirectly (Pygocentrus spp. and Serrasalmus spp.) (Fig. 2A, C, F). The close association of sonic muscles with the anterior chamber of the swimbladder in Catoprion, Pygocentrus and Serrasalmus might be necessary to produce the more complex vocalizations (Fig. 2D, G). In addition, the sonic muscles in all these species show a significant reduction in fibre diameter in comparison to white epaxial fibres, supporting modification at the level of the muscle ultrastructure and the development of fast-contracting muscles (Table 2) usually found in calling species. The genera Pygocentrus and Serrasalmus are characterized by a broader sonic muscle and the correspondingly important basal plate developed on the ventral surface of the proximal part of the second rib (Nelson, 1961). Sonic muscles of Pygopristis denticulata and C. mento are innervated only by branches of the fifth spinal nerve, i.e. the spinal nerve of the intercostal space between ribs 1 and 2 . In contrast, these sonic muscles are innervated by the third and fourth spinal nerves in Serrasalmus rhombeus and by the third, fourth and fifth spinal nerves in Pygocentrus nattereri (Ladich \& Bass, 2005; Onuki et al., 2006; Onuki \& Somiya, 2007). The greater size and differences in innervation pattern of sonic muscles observed in the genera Pygocentrus and Serrasalmus do not seem to be related to the emission of more specialized types of sound, because $C$. mento is able to produce the same types of signals as Pygocentrus and Serrasalmus. Larger sonic muscles would contain more lipids and glycogen, which are important for sustaining high calling rates (Fine et al., 1986; Connaughton et al., 1997; Mitchell et al., 2008). One hypothesis is that larger muscles should allow fish to increase their calling amplitude and the ability to sustain sounds for longer periods of time.

Our hypothesis of the evolutionary history of sound production (Fig. 3) assumes that sound-producing abilities were initially the result of an exaptation 


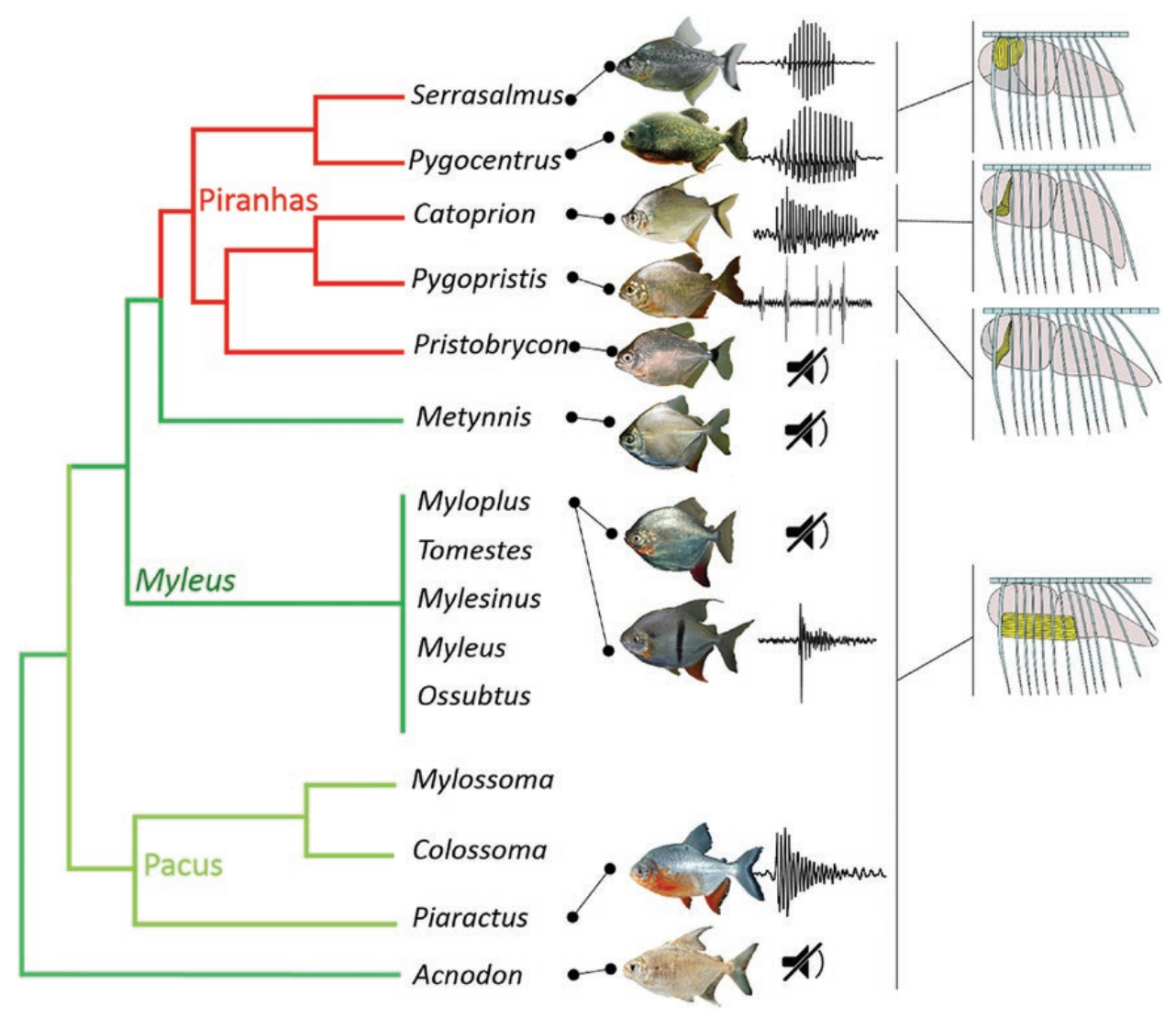

Figure 3. Diagram summarizing data on sound production in the three groups (piranhas, Myleus and pacu) of Serrasalmidae. Pictures of the fish are shown if at least one species of the genus has been tested for sound production. In the tree, red colours correspond to carnivorous species and green colours to herbivorous species. Note that the genus Metynnis is part of the 'true piranhas' clade. The position of the Acnodon and the relationships within the Myleus group are still debated. The tree is based on the studies of Thompson et al. (2014) and Machado et al. (2018).

process. In the second step, structures involved in sound production have been adapted and become more specialized. The anatomy of the sonic apparatus in C. mento and Pygopristis denticulata shows that different mechanisms are used and how a more complex system evolved and has been selected in Serrasalmus and Pygocentrus species. This evolutionary history also involves a transition from a simple pulsation (Piaractus brachypomus and Myloplus schomburgkii) to a more complex vocalization, which has a tonal-like pattern (genera Catoprion, Pygocentrus and Serrasalmus). This pattern of pulse fusion and development of tonal sounds has also been observed in gobies (Malavasi et al., 2008), although the evolution of the sound-producing apparatus is not known in this group. In Serrasalmidae, the species that have sonic muscles in close contact with the swimbladder (C. mento, Pygocentrus spp. and Serrasalmus spp.) are able to produce complex calls (sounds composed of several pulses having a tonallike pattern). However, the genera Catoprion and Pygopristis comprise only one species each, whereas the genera of Pygocentrus and Serrasalmus contain four and 31 species, respectively (Froese \& Pauly, 2019). This higher specific diversity suggests that the morphological configuration found in these taxa, especially Serrasalmus, might provide them with significant advantages in their environment. Moreover, the presence of putative sonic muscles is correlated with tonal-like vocalizations and appears to be parallel to the evolution of predatory (Huby et al., 2019) and aggressive behaviour in piranhas, with acoustic communication being of possible importance during confrontations between conspecifics (Ladich, 1997). The diversification event of piranhas is indeed the most important reported to date for large carnivorous Characiformes (Hubert et al., 2007). The development of sonic muscles and acoustic communication in these fish could potentially be the origin of the evolutionary success of this clade. The diversification process corresponds to the development of the typical sound-producing apparatus of these species. However, the relationship between the ability to produce sounds and the carnivorous lifestyle of these fish remains to be established. Interestingly, the same type of phenomenon has been highlighted 
in a non-phylogenetically related vocal fish taxon. Carapini pearlfish (Carapidae) live in association with echinoderms. In this taxon, a modification in the way of life, from commensal feeding on elusive prey outside of the host to parasitic feeding on host tissue (Parmentier \& Das, 2004), is also related to modifications in both the sound-producing mechanism and the buccal apparatus (Parmentier et al., 2016).

\section{CONCLUSION}

In all existing phylogenetic trees on serrasalmids (Freeman et al., 2007; Hubert et al., 2007; Thompson et al., 2014; Machado et al., 2018) and in a previous study on the evolution of these taxa (Nelson, 1961), herbivorous species have always been placed in a basal position, and carnivorous species are the most derived species (Fig. 3). The acoustic communication supports this point of view. Firstly, herbivorous species lack specialized sonic muscles, but some species are able to produce isolated pulses using anterior hypaxial bundles close to the anterior swimbladder. Secondly, in the carnivorous species Pygopristis, Catoprion, Pygocentrus and Serrasalmus, specialized sound-producing muscles have been acquired, which appear to be derived from the intercostal musculature related to the second rib and are all innervated by spinal nerves. All these features support a common origin. However, the smaller size of the muscle in Pygopristis and Catoprion associated with less complex sounds would confirm their more basal position than Pygocentrus and Serrasalmus (Fig. 3).

The evolutionary history hypothesis of the sound production in piranhas can be explained in a few steps resulting from both exaptation and adaptation. Firstly, during the exaptation event, some hypaxial muscle fibres, inserted between two first ribs, which primarily served locomotion, were co-opted to sound production. The next steps concern adaptation events (Piaractus and Myloplus). Secodly, some intercostal muscle fibres of the first two ribs have changed their orientation and have lengthened, with the caudal insertion moving dorsally towards the rib insertion (Pygopristis). Thirdly, the rostral insertion of the sonic muscles is not on the first rib but has moved on the swimbladder (Catoprion). Fourthly, in more derived forms, the left and right sonic muscles possess a vertical orientation and are both connected ventrally by a common tendon (Serrasalmus and Pygocentrus). All these modifications in muscle insertions appear to have been accompanied by an increase in the innervation network, muscle thickening and sound complexity.

\section{ACKNOWLEDGEMENTS}

We would like to thank Philippe Cerdan and the team of HYDRECO Guyane for their help during field research in French Guiana. This study was supported by grants from F.R.S.-FNRS (Research project no. 23625340) for design of the study, specimen collection, data analysis and writing of the manuscript. G.M. was funded by the Fonds pour la formation à la Recherche dans l'Industrie et l'Agriculture (F.R.S.-FNRS). Finally, we thank reviewers Michael Fine and Sven Horvatic for their helpful comments and suggestions that improved the manuscript.

\section{REFERENCES}

Anderson PSL. 2009. The effects of trapping and blade angle of notched dentitions on fracture of biological tissues. The Journal of Experimental Biology 212: 3627-3632.

Bass AH, Gilland EH, Baker R. 2008. Evolutionary origins for social vocalization in a vertebrate hindbrain-spinal compartment. Science 321: 417-421.

Borie A, Hungria H, Ali H, Doria CR, Fine ML, Travasso PE. 2019. Disturbance calls of five migratory Characiformes species and advertisement choruses in Amazon spawning sites. Journal of Fish Biology in press. doi:10.1111/jfb.14078.

Boyle KS, Riepe S, Bolen G, Parmentier E. 2015. Variation in swim bladder drumming sounds from three doradid catfish species with similar sonic morphologies. The Journal of Experimental Biology 218: 2881-2891.

Calcagnotto D, Schaefer SA, DeSalle R. 2005. Relationships among characiform fishes inferred from analysis of nuclear and mitochondrial gene sequences. Molecular Phylogenetics and Evolution 36: 135-153.

Colleye O, Vandewalle P, Lanterbecq D, Lecchini D, Parmentier E. 2011. Interspecific variation of calls in clownfishes: degree of similarity in closely related species. BMC Evolutionary Biology 11: 365.

Connaughton MA, Fine ML, Taylor MH. 1997. The effects of seasonal hypertrophy and atrophy on fiber morphology, metabolic substrate concentration and sound characteristics of the weakfish sonic muscle. The Journal of Experimental Biology 200: 2449-2457.

Correa SB, Winemiller KO, LóPez-Fernández H, Galetti M. 2007. Evolutionary perspectives on seed consumption and dispersal by fishes. BioScience 57: 748-756.

Dabrowski K, Rinchard J, Ottobre JS, Alcantara F, Padilla P, Ciereszko A, De Jesus MJ, Kohler CC. 2003. Effect of oxygen saturation in water on reproductive performances of Pacu Piaractus brachypomus. Journal of the World Aquaculture Society 34: 441-449.

Fine ML, Parmentier E. 2015. Mechanisms of sound production. In: Ladich F, ed. Sound communication in fishes. Vienna: Springer, 77-126.

Fine ML, Pennypacker KR, Drummond KA, Blem CR. 1986. Concentration and location of metabolic substrates in fast toadfish sonic muscle. Copeia 4: 910-915.

Freeman B, Nico LG, Osentoski M, Jelks HL, Collins TM. 2007. Molecular systematic of Serrasalmidae: deciphering the identities of piranha species and unraveling their evolutionary histories. Zootaxa 1484: 1-38. 
Froese R, Pauly D. 2019. FishBase. Available at: www. fishbase.org/

Godinho AL, Silva CCF, Kynard B. 2017. Spawning calls by zulega, Prochilodus argenteus, a Brazilian riverine fish. Environmental Biology of Fishes 100: 519-533.

Hallacher LE. 1974. The comparative morphology of extrinsic gasbladder musculature in the scorpionfish genus Sabastes (Pisces: Scorpaenidae). Proceedings of the California Academy of Sciences 40: 59-86.

Hubert N, Duponchelle F, Nunez J, Garcia-Davila C, Paugy D, Renno JF. 2007. Phylogeography of the piranha genera Serrasalmus and Pygocentrus: implications for the diversification of the Neotropical ichthyofauna. Molecular Ecology 16: 2115-2136.

Huby A, Lowie A, Herrel A, Vigouroux R, Frédérich B, Raick X, Kurchevski G, Godinho AL, Parmentier E. 2019. Functional diversity in biters: the evolutionary morphology of the oral jaw system in pacus, piranhas and relatives (Teleostei: Serrasalmidae). Biological Journal of the Linnean Society blz048.

Kastberger G. 1981a. Economy of sound production in piranhas (Serrasalminae, Characidae): I. Functional properties of sonic muscles. Zoologische Jahrbücher Physiologie 85: 113-125.

Kastberger G. 1981b. Economy of sound production in piranhas (Serrasalminae, Characidae): II. Functional properties of sound emitter. Zoologische Jahrbücher Physiologie 85: 393-411.

Ladich F. 1997. Agonistic behaviour and significance of sounds in vocalizing fish. Marine and Freshwater Behaviour and Physiology 29: 87-108.

Ladich F. 2015. Acoustic signalling in female fish In: Ladich F, ed. Sound communication in fishes. Wien: Springer-Verlag 149-173.

Ladich F, Bass AH. 2005. Sonic motor pathways in piranhas with a reassessment of phylogenetic patterns of sonic mechanisms among teleosts. Brain, Behavior and Evolution 66: 167-176.

Ladich F, Fine ML. 2006. Sound-generating mechanisms in fishes: a unique diversity in vertebrates. In: Ladich F, Collin SP, Moller P, Kapoor BG, eds. Communication in Fishes. Enfield: Science Publishers, 3-34.

Machado VN, Collins RA, Ota RP, Andrade MC, Farias IP, Hrbek T. 2018. One thousand DNA barcodes of piranhas and pacus reveal geographic structure and unrecognised diversity in the Amazon. Scientific Reports 8: 8387.

Malavasi S, Collatuzzo S, Torricelli P. 2008. Interspecific variation of acoustic signals in Mediterranean gobies (Perciformes, Gobiidae): Comparative analysis and evolutionary outlook. Biological Journal of the Linnean Society 93: 763-778.

Markl H. 1971. Schallerzeugung bei Piranhas (Serrasalminae, Characidae). Zeitschrift für vergleichende Physiologie 74: 39-56.

Mélotte G, Vigouroux R, Michel C, Parmentier E. 2016. Interspecific variation of warning calls in piranhas: a comparative analysis. Scientific Reports 6: 36127.

Millot S, Parmentier E. 2014. Development of the ultrastructure of sonic muscles : a kind of neoteny ? BMC Evolutionary Biology 14: 1-9.
Millot S, Vandewalle P, Parmentier E. 2011. Sound production in red-bellied piranhas (Pygocentrus nattereri, Kner): an acoustical, behavioural and morphofunctional study. The Journal of Experimental Biology 214: 3613-3618.

Mitchell S, Poland J, Fine ML. 2008. Does muscle fatigue limit advertisement calling in the oyster toadfish Opsanus tau? Animal Behaviour 76: 1011-1016.

Mok HK, Parmentier E, Chiu KH, Tsai KE, Chiu PH, Fine ML. 2011. An intermediate in the evolution of superfast sonic muscles. Frontiers in Zoology 8: 31.

Myrberg JAA, Lugli M. 2006. Reproductive behavior and acoustic communication. In: Ladich F, Collin SP, Moller P, Kapoor BG, eds. Communication in fishes. Endfield: Science Publishers, 149-176.

Nelson EM. 1961. The swim bladder in the Serrasalminae with notes on additional morphological features. Feldania Zoology 39: 603-624.

Onuki A, Ohmori Y, Somiya H. 2006. Spinal nerve innervation to the sonic muscle and sonic motor nucleus in red piranha, Pygocentrus nattereri (Characiformes, Ostariophysi). Brain, Behavior and Evolution 67: 111-122.

Onuki A, Somiya H. 2007. Innervation of sonic muscles in teleosts: occipital vs. spinal nerves. Brain Behaviour and Evolution 69: 132-141.

Ordway GA, Garry DJ. 2004. Myoglobin: an essential hemoprotein in striated muscle. Journal of Experimental Biology 207: 3441-3446.

Orti G, Sivasundar A, Dietz K, Jégu M. 2008. Phylogeny of the Serrasalmidae (Characiformes) based on mitochondrial DNA sequences. Genetics and Molecular Biology 31: 343-351.

Parmentier E, Das K. 2004. Commensal vs. parasitic relationship between Carapini fish and their hosts: some further insight through $\delta 13 \mathrm{C}$ and $\delta 15 \mathrm{~N}$ measurements. Journal of Experimental Marine Biology and Ecology 310: 47-58.

Parmentier E, Diogo R. 2006. Evolutionary trends of swimbladder sound mechanisms in some teleost fishes. In: Ladich F, Collin SP, Moller P, Kapoor BG, eds. Communication in fishes. Enfield: Science Publishers, 45-70.

Parmentier É, Diogo R, Fine ML. 2017. Multiple exaptations leading to fish sound production. Fish and Fisheries 18: 958-966.

Parmentier E, Lanterbecq D, Eeckhaut I. 2016. From commensalism to parasitism in Carapidae (Ophidiiformes): Heterochronic modes of development? PeerJ 4: e1786.

Parmentier E, Vandewalle P, Brié C, Dinraths L, Lecchini D. 2011. Comparative study on sound production in different Holocentridae species. Frontiers in Zoology 8: 12.

Planquette $\mathbf{P}$, Keith P, Le Bail PY. 1996. Atlas des poissons d'eau douce de Guyane: Tome 1. Paris: Publications scientifiques du Muséum national d'Histoire Naturelle.

Raick X, Lecchini D, Kéver L, Colleye O, Bertucci F, Parmentier É. 2018. Sound production mechanism in triggerfish (Balistidae): a synapomorphy. The Journal of Experimental Biology 221: jeb168948.

Ramcharitar JU, Gannon DP, Popper AN. 2006. Bioacoustics of fishes of the family Scianidae (croackers and 
drums). Transactions of the American Fisheries Society 135: 1409-1431.

Ramirez JL, Birindelli JLO, Galetti PM. 2017. A new genus of Anostomidae (Ostariophysi: Characiformes): diversity, phylogeny and biogeography based on cytogenetic, molecular and morphological data. Molecular Phylogenetics and Evolution 107: 308-323.

Randall JA. 2001. Evolution and function of drumming as communication in mammals. American Zoologist 41: 1143-1156.

Reynalte-Tataje DA, Lopes CA, de Avila-Simas S, Garcia JRE, Zaniboni-Filho E. 2013. Artificial reproduction of neotropical fish: extrusion or natural spawning? Natural Science 5: 1-6.

Rice AN, Bass AH. 2009. Novel vocal repertoire and paired swimbladders of the three-spined toadfish, Batrachomoeus trispinosus: insights into the diversity of the Batrachoididae. The Journal of Experimental Biology 212: 1377-1391.

Rome LC, Syme DA, Hollingworth S, Lindstedt SL, Baylor SM. 1996. The whistle and the rattle: the design of sound producing muscles. Proceedings of the National Academy of Sciences of the United States of America 93: 8095-8100.
Rountree RA, Juanes F. 2018. Potential for use of passive acoustic monitoring of piranhas in the Pacaya-Samiria National Reserve in Peru. Freshwater Biology. doi:10.1111/fwb.13185.

Schaller F. 1971. Über den Lautapparat von AmazonasFischen. Naturwissenschaften 58: 573-574.

Scott JL, Kawahara AY, Skevington JH, Yen SH, Sami A, Smith ML, Yack JE. 2010. The evolutionary origins of ritualized acoustic signals in caterpillars. Nature Communications 1: 4 .

Smith ME, Weller KK, Kynard B, Sato Y, Godinho AL. 2018. Mating calls of three prochilodontid fish species from Brazil. Environmental Biology of Fishes 101: 327-339.

Thompson AW, Betancur-R R, López-Fernández H, Ortí G. 2014. A time-calibrated, multi-locus phylogeny of piranhas and pacus (Characiformes: Serrasalmidae) and a comparison of species tree methods. Molecular Phylogenetics and Evolution 81: 242-257.

Tinbergen N. 1952. 'Derived' activities; their causation, biological significance, origin, and emancipation during evolution. The Quarterly Review of Biology 27: 1-32.

Winterbottom R. 1974. A descriptive synonymy of the striated muscles of the teleostei. Proceedings of the Academy of Natural Sciences of Philadelphia 125: 225-317.

\section{SUPPORTING INFORMATION}

Additional Supporting Information may be found in the online version of this article at the publisher's web-site:

Figure S1. Waveform (above) and spectrogram (below) of the sound produced by Myloplus schomburgkii. Sounds were recorded at $44.1 \mathrm{kHz}$.

Figure S2. Waveform (above) and spectrogram (below) of the second type of sound produced by Pygopristis denticulata. Sounds were recorded at $44.1 \mathrm{kHz}$. 